\title{
Low Recombination Firing-Through Al Paste for N-Type Solar Cell with Boron Emitter
}

\author{
Peng Zhu ${ }^{1}$, Yuan Liu ${ }^{1,2, *} \mathbb{C}$, Chengjiang Cao ${ }^{1}$, Juan Tian ${ }^{3}$, Aichuang Zhang ${ }^{1}$ and Deliang Wang ${ }^{3, *}$ \\ 1 College of Chemistry and Chemical Engineering, Nantong University, Nantong 226019, China; \\ pzhu@ntu.edu.cn (P.Z.); 1908320010@stmail.ntu.edu.cn (C.C.); 2007320013@stmail.ntu.edu.cn (A.Z.) \\ 2 Jiangsu Province Cultivation Base for State Key Laboratory of Photovoltaic Science and Technology, \\ Changzhou University, Changzhou 213164, China \\ 3 Hefei National Laboratory for Physical Sciences at Microscale, University of Science and Technology of China, \\ Hefei 230026, China; tian999@mail.ustc.edu.cn \\ * Correspondence: liuyuan1105@ntu.edu.cn (Y.L.); eedewang@ustc.edu.cn (D.W.)
}

check for

updates

Citation: Zhu, P.; Liu, Y.; Cao, C.; Tian, J.; Zhang, A.; Wang, D. Low Recombination Firing-Through Al Paste for N-Type Solar Cell with

Boron Emitter. Materials 2021, 14, 765. https://doi.org/10.3390/ma14040765

Academic Editor: Federico Bella

Received: 19 January 2021

Accepted: 2 February 2021

Published: 6 February 2021

Publisher's Note: MDPI stays neutral with regard to jurisdictional claims in published maps and institutional affiliations.

Copyright: (c) 2021 by the authors. Licensee MDPI, Basel, Switzerland. This article is an open access article distributed under the terms and conditions of the Creative Commons Attribution (CC BY) license (https:// creativecommons.org/licenses/by/ $4.0 /)$.

\begin{abstract}
A kind of low recombination firing-through screen-printing aluminum (Al) paste is proposed in this work to be used for a boron-diffused $\mathrm{N}$-type solar cell front side metallization. A front side fire-through contact (FTC) approach has been carried out for the formation of local contacts for a front surface passivated solar cell. With a low contact resistivity $\left(\rho_{\mathrm{c}}\right)$ of $1.0 \mathrm{~m} \Omega \cdot \mathrm{cm}^{2}$, good ohmic contact between the boron-doped front surface of the silicon sample and the Al paste was realized. To obtain a good energy conversion efficiency, a balance can be achieved between the open circuit voltage $\left(\mathrm{V}_{\mathrm{oc}}\right)$ and contact resistivity $\left(\rho_{\mathrm{c}}\right)$ of the cell by combining suitable $\mathrm{Al}$ powders and appropriate additives. The detailed micro-contact difference in $\mathrm{Si} /$ metallization between the firing-through $\mathrm{Al}$ paste and silver-aluminum ( $\mathrm{Ag}-\mathrm{Al})$ paste was analyzed. The dark saturation current density beneath the metal contact $\left(\mathrm{J}_{0}\right.$, metal $)$ of the $\mathrm{Si} /$ metallization region using our firing-through $\mathrm{Al}$ paste was discussed, which was proven to be $61 \%$ lower than using Ag-Al paste. The pseudo energy conversion efficiency of the cell using $\mathrm{Al}$ paste measured by Suns- $\mathrm{V}_{\mathrm{OC}}$ was also higher than using $\mathrm{Ag}-\mathrm{Al}$ paste. The role of $\mathrm{Al}$ paste in low surface metal recombination is discussed. The utilization of this new kind of $\mathrm{Al}$ paste was much cheaper and more convenient, compared to the traditional process using Ag or Ag-Al paste.
\end{abstract}

Keywords: low recombination; fire-through; aluminum paste; N-type solar cell; boron emitter

\section{Introduction}

Over recent decades, silicon (Si) solar cells have been widely used in various lighting and power generation systems. Electric power using solar cells through photoelectric conversion from solar energy can be obtained as a pollution-free and high supply resource. A passivated emitter and rear cell (PERC) based on P-type Czochralski-grown silicon (CzSi) substrate has been introduced into production [1]. However, with absence light induced degradation (LID), higher lifetimes of minority charge carriers, and lower sensitivity towards metal impurities, $\mathrm{N}$-type solar cells could offer greater efficiency possibilities and advantages over P-type solar cells [2-7].

There is no doubt that the metallization process forming the electrode has turned out to be an important part of the enhancement of energy conversion efficiency, which adopts screen-printing paste composed of metal particles, low-melting glass frits and an organic part. Nowadays, silver (Ag) pastes applicable for the metallization of bifacial $\mathrm{N}$-type solar cells through screen-printing technology are commonly investigated by many researchers [8-17]. For the formation of ohmic contact on the boron-doped emitter, since the mechanism is more complicated, many attempts have been made to improve the semiconductor-metal contact. Some reports have proved that the contact resistivity between the electrode and the Si substrate could be remarkably reduced by adding aluminum 
particle to the Ag paste to form silver-aluminum (Ag-Al) paste [18-24]. On the other hand, with the presence of the $\mathrm{Al}$ particle, some inappropriate $\mathrm{Ag} / \mathrm{Al}$ spikes can give birth to a larger dark saturation current beneath the paste contact area [25-27]. Lago's group proved that the spiking problem could be solved by adding silicon powder to the metallization paste [23]. Subsequently, Lohmülle et al. suggested that increasing the junction depth (deeper than $1 \mu \mathrm{m}$ ) or the formation of $\mathrm{Ag}$ nanocrystals can reduce the recombination loss beneath the Ag-Al contact [28]. In 2016, it was reported by Kumar et al. that 20\% efficiency had been reached using $\mathrm{Ag}$ - $\mathrm{Al}$ paste [21].

However, the large-scale application of N-type silicon solar cells has also been limited by the cost of the wafer and bifacial Ag paste. It has been an urgent issue to cut down the cost of N-type silicon solar cells. In particular, aluminum conductive paste has become an important material for the back side metallization in the formation of the back surface field (BSF) in P-type silicon solar cells [29-31]. In this case, the charge carrier's lifetime could be significantly prolonged. Light transmission and the charge carrier's neutralization could also be reduced. Good performance of the solar cell could be achieved with this cost-effective option. However, rather than forming regenerative nanoparticles, aluminum electrodes on a boron-doped emitter of ohmic contact should be more difficult. Few reports on $\mathrm{Al}$ paste being applicable for the front side metallization of $\mathrm{N}$-type solar cells have been published up to now. On the basis of the expected performance of $\mathrm{Al}$ paste with low surface recombination of the wafers [32], $\mathrm{Al}$ conductive paste should be considered as an alternative anode conductive material for the front side boron emitter metallization of $\mathrm{N}$-type silicon solar cells. The utilization of an Al electrode on the boron-doped emitter could be acquired at both high photoelectric conversion efficiency and low cost.

There are three approaches for the formation of local ohmic contact in front surface passivated solar cells: chemical structuring, laser process and fire-through contact (FTC) [33]. Usually, the creation of local contacts in the fabrication of PERC solar cells can be realized by a chemical structuring or laser process resulting in local ohmic contacts during co-firing, which is prone to seriously damage the passivation layer. A fire-through contact approach, employing a screen printing process and leading to no damage of the passivation layer before firing, contribute to the integration of bifacial passivation concepts in traditional production lines.

In this work, a type of firing-through $\mathrm{Al}$ screen-printing paste applied on the borondoped emitter $\mathrm{N}$-type solar cell is presented. The fire-through contact approach for the $\mathrm{N}$ type passivated emitter and rear totally diffused (N-PERT) solar cell with a screen-printed approach is evaluated. The investigation of the contact mechanism between the Al paste and $\mathrm{Si}$ wafer has been carried out through micro-structure analysis at the $\mathrm{Si} /$ metallization interface. Both the $\mathrm{Al}$ powder and the additive of the $\mathrm{Al}$ paste were checked to understand the formation process of ohmic contact on the front side metallization for the silicon solar cell. Based on this, the passivation layer could be etched away with Al paste. Afterwards, ohmic contact with the Si substrate could be formed by optimizing the constituents of the paste. Good ohmic contact, between the boron-doped front surface of the silicon wafer and the Al paste, for a front electrode was realized, with low contact resistivity $\rho c$ at $1.0 \mathrm{~m} \Omega \cdot \mathrm{cm}^{2}$. To obtain good energy conversion efficiency, a balance can be achieved between the open circuit voltage $\left(\mathrm{V}_{\mathrm{OC}}\right)$ and contact resistivity $\left(\rho_{\mathrm{c}}\right)$ by adding appropriate additives. The role of the Al paste in low surface recombination is also discussed. The experimentally extracted dark saturation current density beneath the metal contact $\left(\mathrm{J}_{0, \text { metal }}\right)$ in the front side of the silicon cell using our aluminum paste was determined by Suns-Voc, and was proven to be $61 \%$ lower. The energy conversion efficiency is $0.4 \%$ higher than that of $\mathrm{Ag}-\mathrm{Al}$ paste. Compared with the traditional process by using $\mathrm{Ag}$ or $\mathrm{Ag}-\mathrm{Al}$ paste for the boron-doped emitter, it is much cheaper and more convenient using Al paste, which is instructive and significant for the current transmission mechanism of $\mathrm{Si} /$ metallization and improved application of $\mathrm{Al}$ conduction pastes. 


\section{Materials and Methods}

In this study, $156 \times 156 \mathrm{~mm}^{2} \mathrm{~N}$-type $\mathrm{Cz}$ silicon wafers with base doping of $1 \Omega \cdot \mathrm{cm}$ were used. The $\mathrm{p}^{+}$(boron) diffused regions with a thickness of $0.5 \mu \mathrm{m}$ were formed with a sheet resistance of $90 \Omega /$ sq. at the front side of n-type Si substrate. The $\mathrm{n}^{+}$(phosphorous) diffused regions with a thickness of $120 \mathrm{~nm}$ were formed with a sheet resistance of $25 \Omega$ /sq. at the back side. This diffused region was passivated by a $1-2 \mathrm{~nm} \mathrm{Al}_{2} \mathrm{O}_{3}$ layer covered with a $70 \mathrm{~nm}$ anti-reflection $\mathrm{SiN}_{\mathrm{x}}$ layer on the sample exterior surface. The $\mathrm{SiNx}$ and $\mathrm{Al}_{2} \mathrm{O}_{3}$ layers were prepared by plasma-enhanced chemical vapor deposition (PECVD). The manufacturing process and the structure diagram of the $\mathrm{N}$ type passivated emitter and rear totally-diffused (N-PERT) solar cell are shown in Figure 1.

(a)

\begin{tabular}{|c|}
\hline $156 \times 156 \mathrm{~mm}^{2} \mathrm{~N}$-type Si substrate \\
\hline Texturing(TEX) \\
\hline Boron Diffusion (BBr ${ }_{3}$ BDF) \\
\hline Etching(SSE) \\
\hline Implanted phosphorus (IMP) \\
\hline Cleaning(RCA) \\
\hline Annealing(ANN) \\
\hline Rear coating ( ARC-R) \\
\hline Front passivation layer ( ALD) \\
\hline Metalization \\
\hline
\end{tabular}

(b)

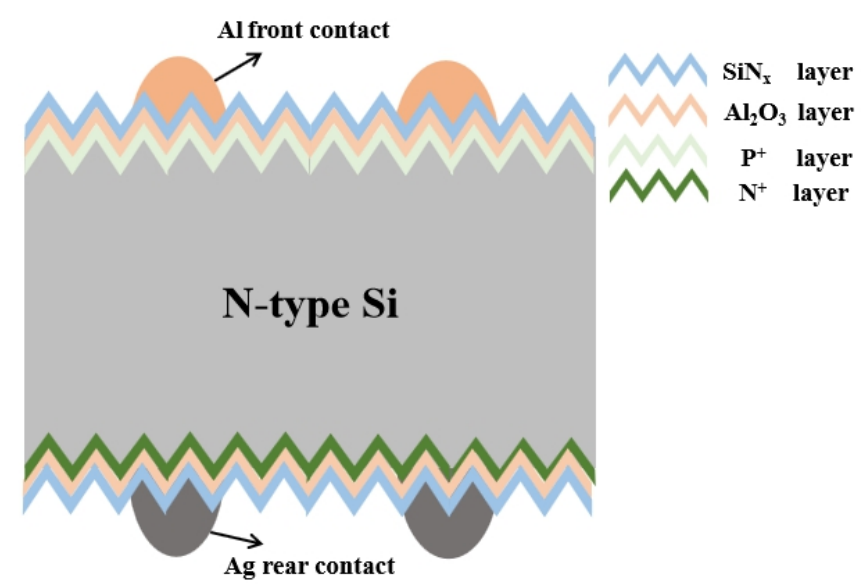

Figure 1. (a) The manufacturing process; (b) the structure diagram of N-PERT solar cells.

The firing-through $\mathrm{Al}$ paste used in this paper consists of $\mathrm{Al}$ powder $(74 \mathrm{wt} \%)$, glass frit $(5 \mathrm{wt} \%)$ and an organic part $(21 \mathrm{wt} \%)$. The ingredients above were mixed together then made into paste through centrifugal dispersion and three-roll grinder. The Ag-Al paste used on the front side of cell as a comparison was also a present state-of-the-art product for the N-type solar cell. A commercial silver (Ag) paste (Nantong T-Sun New energy Co., Ltd., Nantong, China) was used for the rear side metallization of the cell. The metallization process on both sides of the wafers was employed by screen-printing metal pastes with an $\mathrm{H}$-pattern grid design undergoing the screen printing process. The screen printer was purchased from Baccini (Treviso, Italy). Afterwards the samples were fired in a belt sintering furnace with a peak temperature of $750-760{ }^{\circ} \mathrm{C}$.

An image of a completed solar cell is shown in Figure 2, which has 5 bus bars and 106 fingers of metal paste lines. In this paper, the electrical characterizations of the solar cell as in Figure 2 were analyzed with light under standard AM1.5 illumination $\left(1 \mathrm{~kW} / \mathrm{m}^{2}\right.$, $25^{\circ} \mathrm{C}$ ) and dark IV measurements on a solar J-V tester (IVT Solar Pte Ltd., Shanghai, China) [34]. Besides, the implied electrical properties of the cell were measured by Suns-Voc (Boulder, CO, USA). A transfer length model (TLM) method on 10-mm-width stripes with equidistant metallization lines has been applied to acquire the contact resistivity $\left(\rho_{\mathrm{C}}\right)$ [35].

To obtain the recombination current density beneath the metal contact $\left(\mathrm{J}_{0, \text { metal }}\right)$, different front side screen-printing patterns with metallization fractions of $3 \%, 6 \%, 9 \%$ and $12 \%$ have been designed by changing the number of the screen-printed fingers, as shown in Figure 3 . The measured $\mathrm{J}_{01}$ by Suns- $\mathrm{V}_{\mathrm{OC}}$ can represent the recombination of the entire cell when the ideality is about 1 [36]. According to [36-38], the slope of the linear regression of the $\mathrm{J}_{01}$ vs. metallization fraction allows determination of the $\left(\mathrm{J}_{0 \text {, metal }}-\mathrm{J}_{0 \text {, pass }}\right)$. The recombination current density $\left(\mathrm{J}_{0, \text { pass }}\right)$ of emitter passivation, known from experimentally fully passivated areas, is around $25 \mathrm{fA} / \mathrm{cm}^{2}$. 


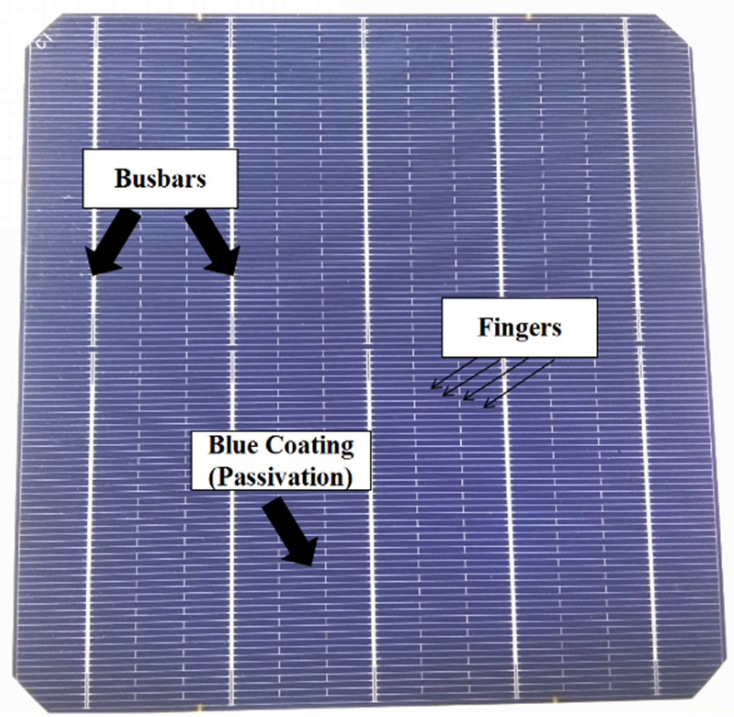

Figure 2. Image of a completed solar cell.

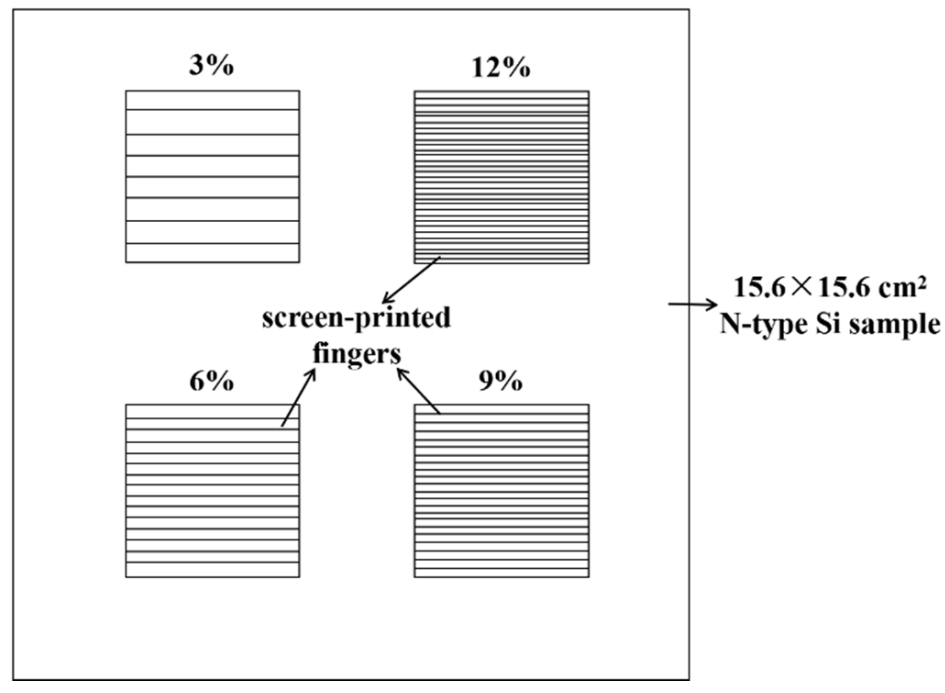

Figure 3. The screen-printing pattern of the sample with different metallization fraction from $3 \%$ to $12 \%$.

The detailed micro-structure analysis at the cell surface region has also been developed by a field-emission scanning electron microscope and energy dispersive spectroscopy (EDS) (FE-SEM, Sirion 200, HITACHI, Tokyo, Japan). The SEM of the Si substrate surface was taken after soaking the cell in $60 \%$ nitric acid for $10 \mathrm{~min}$ to remove the paste.

\section{Results}

\subsection{The Mechanism of Ohmic Contact between Al Paste and Si Substrate}

N-PERT solar cells using Ag-Al paste and firing-through Al paste for boron-doped emitter metallization are denoted as Cell 1 and Cell 2, respectively. The distribution of measured contact resistivity $\left(\rho_{\mathrm{c}}\right)$ and open circuit voltage $\left(\mathrm{V}_{\mathrm{OC}}\right)$ of the investigated solar cell with Ag-Al paste and Al paste are shown in Figure 4, and the average value is displayed above each box plot. To our knowledge, it is the first result of a solar cell proving that $\mathrm{Al}$ paste could be applied at the front side boron emitter in the $\mathrm{N}$-type solar cell. Compared with Ag-Al paste, slightly higher $\rho_{\mathrm{c}}$ through Al metallization was yielded, while higher $\mathrm{V}_{\mathrm{OC}}$ were obtained. This indicates that the firing-through $\mathrm{Al}$ paste is a promising candidate 
for the metallization of the boron emitter for improved performance of $\mathrm{N}$-type silicon solar cells [36].

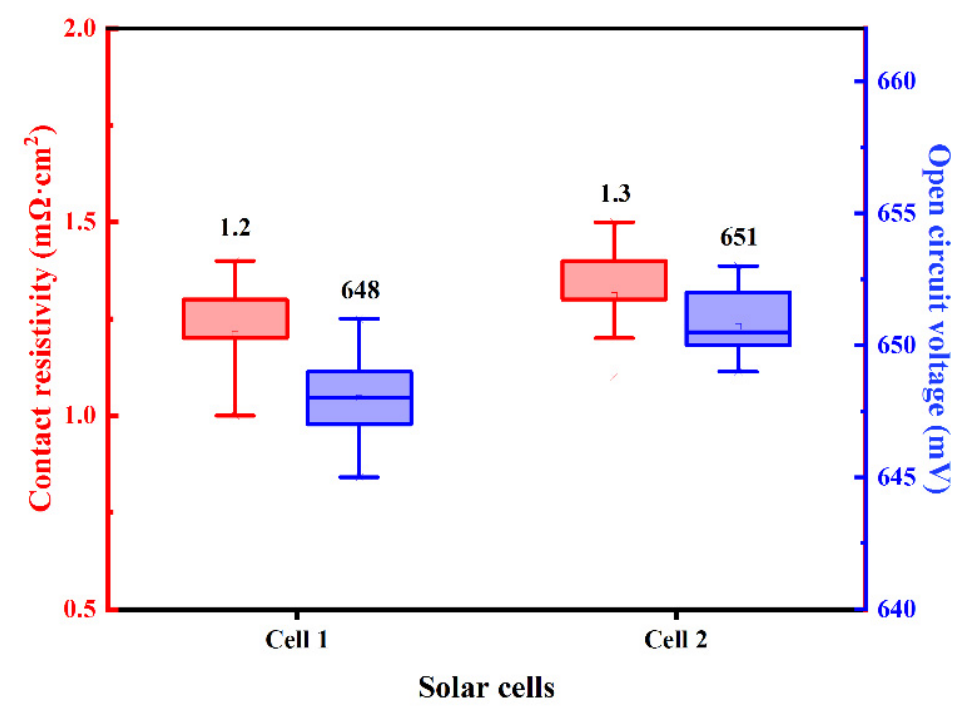

Figure 4. The distribution of the $\rho_{\mathrm{c}}$ and $\mathrm{V}_{\mathrm{OC}}$ of the solar cells using Ag-Al paste and $\mathrm{Al}$ paste.

The $\mathrm{J}_{01}$ values of the small solar cells metallized with Ag-Al paste and firing-through Al paste using the printed pattern mentioned above are shown in Figure 5. The solar cell metallized with the firing-through $\mathrm{Al}$ paste yield as significantly lower $\mathrm{J}_{0 \text {, metal }}$ compared with that of the cell using the Ag-Al paste. This indicates that the firing-through $\mathrm{Al}$ paste is a promising candidate for the metallization of the boron emitter to obtain a lower metal recombination and improved performance of N-type silicon solar cells [36].

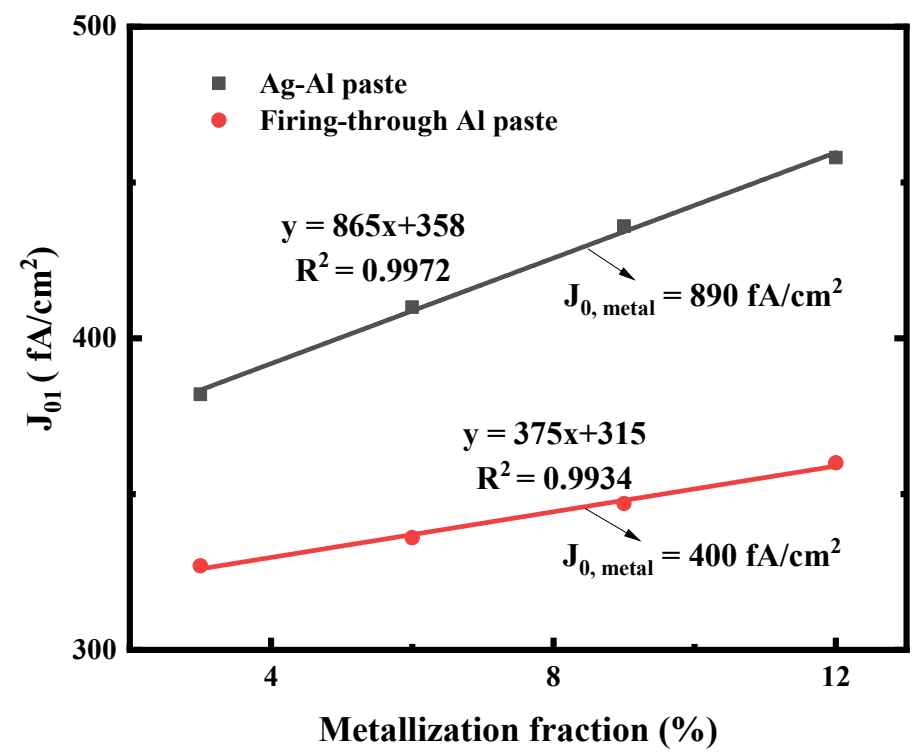

Figure 5. $\mathrm{J}_{01}$ extracted from Suns- $\mathrm{V}_{\mathrm{OC}}$ as a function of metal fraction variation on the cell boron emitter. The $\mathrm{J}_{0, \text { metal }}$ is then extracted from the linear fit (solid lines).

The dark J-V curves of Cell 1 and Cell 2 shown in Figure 6 demonstrate that the Al paste makes a contribution to a lower current leakage current density when applying a backward voltage, which implies much fewer defects in the Cell 2 resulting from Al paste. At high forward voltages, the two dark J-V curves demonstrate a typical exponential current increase with the voltage, indicating low Rs of the two cells, which is consistent 
with the contact resistivity results shown in Figure 4. To confirm the performance of metallization, more work including analysis of microstructure and component influences is needed to investigate the mechanism of ohmic contact between the metal and Si substrate.

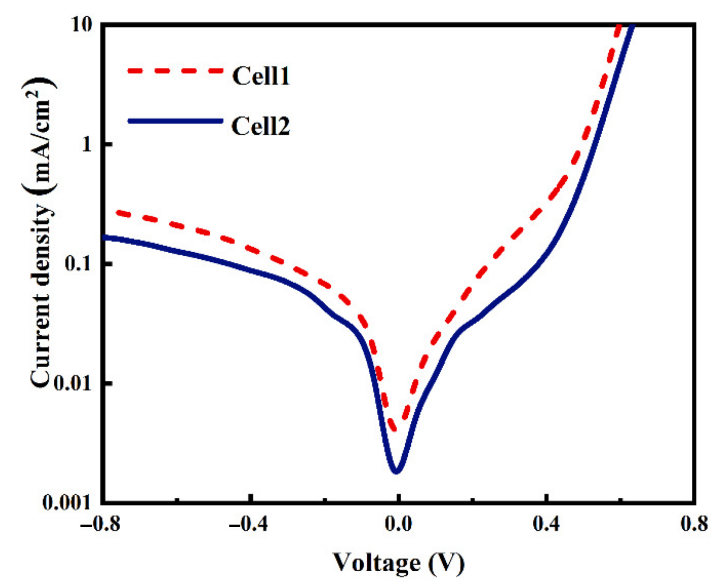

Figure 6. Dark J-V curves of the two cells using Ag-Al paste and firing-through Al paste.

The microstructural properties of the $\mathrm{Si} /$ metallization interface are examined by SEM at $10 \mathrm{kV}$. SEM results confirmed that the damage to the Si wafer was caused by metal paste. The typical Ag-Al paste/Si substrate microstructure is shown in Figure 7a. The Ag-bulk/Si contact in p+ emitter has been studied in detail $[9,11,12,16]$, and the glass frit can etch away the passivation layer through firing-through contact technology. As reported [13], the glassy-phase plays an important role in contact properties, in which regenerated nanoAg particles are dissolved to form Ag colloids. The Ag colloids with the glassy-phase assist the current tunneling with the intention of realizing current transmission through the glass phase. The SEM image of the $\mathrm{Si} /$ metallization interface after the metal paste was removed is shown in Figure 7c. A continuous phase containing Ag colloids was observed at this region, which is the same as reported: that the combination influences of dissolved Ag particles and glassy-phase have crucial effects on the current transport across the interface [21].

(a)

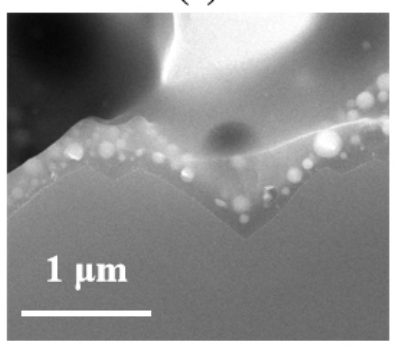

(c)

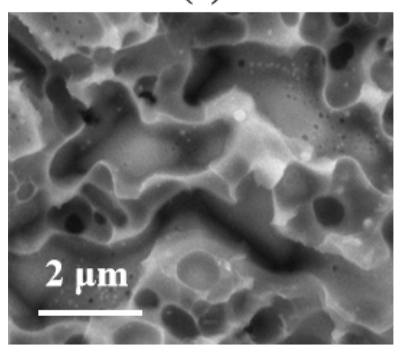

(b)

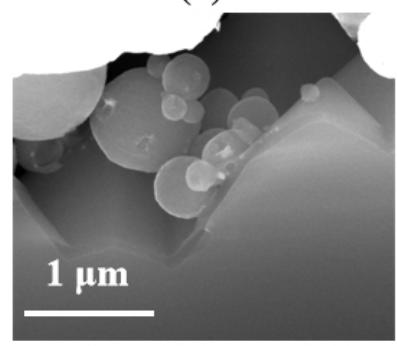

(d)

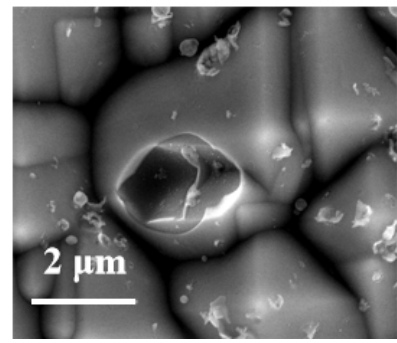

Figure 7. (a,b) Cross section scanning electron microscope (SEM) images of Cell 1 and Cell 2, obtained at the Si/metallization interface; (c,d) SEM images of Si substrate surface etched area after the paste removal. 
However, the SEM micrographs in Figure $7 \mathrm{~b}$ show that the glass frit did not facilitate the precipitate containing $\mathrm{Al}$ particles in the contact region, which was also proven in the $\mathrm{Si} /$ metallization interface in Figure $7 \mathrm{~d}$. The optimally fired-through contact was implemented to clarify the pattern of current transmission between the Al paste and the Si substrate. We suggest that the current transmission between the firing-through $\mathrm{Al}$ paste and the Si substrate was formed by a direct contact and a current tunneling between $\mathrm{Al}$ bulk and the silicon substrate through the 1-2 nm thin $\mathrm{Al}_{2} \mathrm{O}_{3}$ layer. It is also interesting that, without the continuous glassy-phase on the surface of $\mathrm{Si}$ substrate, less etched region was found in the $\mathrm{Al} / \mathrm{Si}$ substrate interface. The reserved area of passivation layer shows no obvious damage, leading to reserved passivation.

EDS analyses were also employed to examine the reaction between the $\mathrm{Al}$ paste and the passivation layer $\left(\mathrm{SiN}_{\mathrm{x}}\right)$. The cross-sectional microstructures of the $\mathrm{Si} / \mathrm{metallization}$ region without an $\mathrm{Al}$ particle directly attached are shown in Figure 8a. The element mapping images of this region are shown in Figure $8 \mathrm{~b}-\mathrm{d}$ correspondingly. According to a previous study on the sintering mechanism of Ag paste [10-15], these "voids" in the passivation stack area (Figure 8a) are formed by the $\mathrm{N}_{2}$ produced from the reaction between the glass frit and $\mathrm{SiN}_{\mathrm{x}}$, given the composition of glass frit used in our $\mathrm{Al}$ paste. The element mapping results also confirm that no $\mathrm{O}$ element is contained in the "voids" area. In Figure $8 \mathrm{~b}, \mathrm{~d}$, the existence of the continuous $\mathrm{O}$ layer and $\mathrm{Al}$ layer proved that the $\mathrm{Al}_{2} \mathrm{O}_{3}$ layer was kept without damage. Besides, it is illustrated in Figure 8c that, devoid of the continuous glass phase, when dissolving nano metal colloids on the surface of the $\mathrm{Si}$ wafer, the $\mathrm{SiN}_{\mathrm{x}}$ layer was partially reserved. The remaining $\mathrm{SiN}_{\mathrm{x}}$ layer could perform surface passivation, which gives rise to the low metal recombination of the solar cell.

(a)

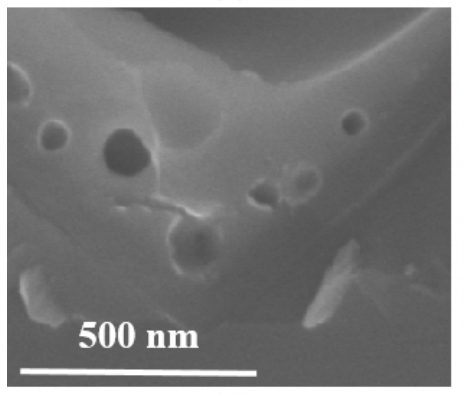

(c)

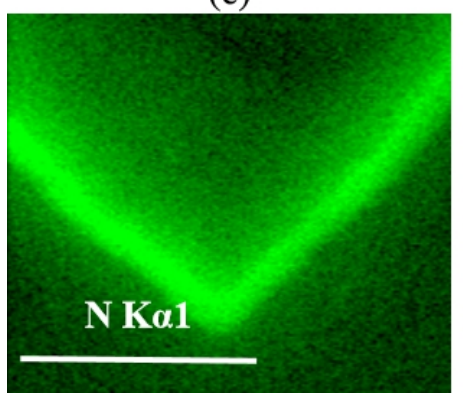

(b)

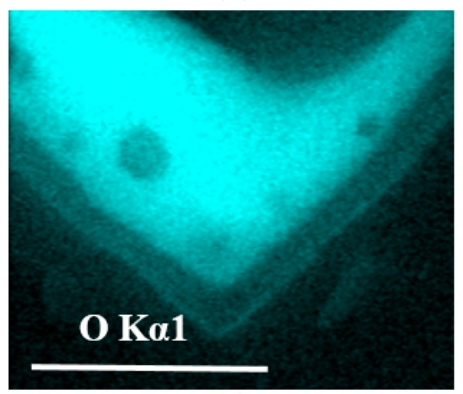

(d)

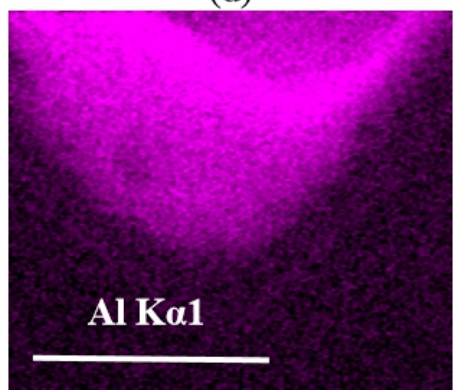

Figure 8. (a) $\mathrm{Si} /$ metallization interface SEM images of Cell 2; (b-d) Energy dispersive spectroscopy (EDS) mapping images obtained at $\mathrm{Si} /$ metallization contact area shown in (a). Different element such as $\mathrm{O}, \mathrm{N}, \mathrm{Al}$ are identified as different colors.

Unlike the semiconductor-metal contact through the nano-Ag particle dissolved in the glass phase, the contact between $\mathrm{Al}$ paste and the Si substrate was produced in default of the assistance of the regenerative nano metal colloids. Those Si/metallization contact regions without an $\mathrm{Al}$ particle directly attached cannot collect current, as the $\mathrm{SiN}_{\mathrm{x}}$ layer exists. The contact mechanism between Al paste and Si substrate has to be considered under the influence of comparatively large-scale Al particles. High and low magnification SEM 
images in Figure 9a,b were used to further characterize the micro-contact $\mathrm{Si} /$ metallization interface. The Al particles maintained a good spherical shape during the firing process resulting in a discontinuous contact with the Si substrate. Those areas where the Al particles in direct contact with the Si substrate could collect current from the Si substrate are shown sin Figure $9 \mathrm{~b}$. Because of the existence of gaps between Al particles, the current cannot be collected through some areas on the Si substrate untouched by Al particles. As a result, some obvious etching areas occurred as shown in Figure $7 d$, which engendered a serious recombination at these interfaces. In other words, due to the morphological characteristics of $\mathrm{Al}$ particles, the reaction between the $\mathrm{Al}$ paste and the Si substrate was very uneven.

(a)

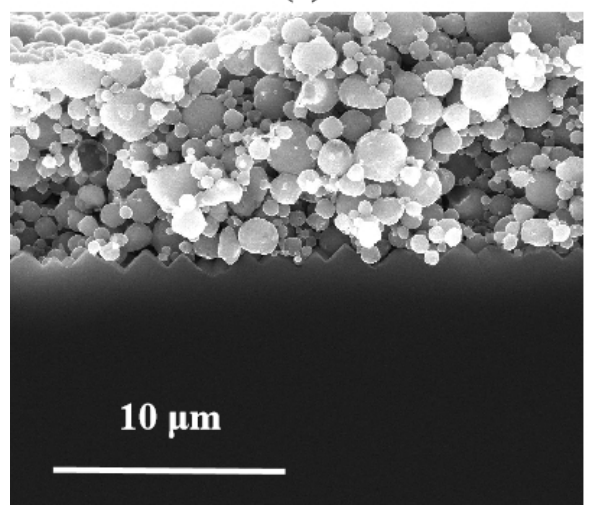

(b)

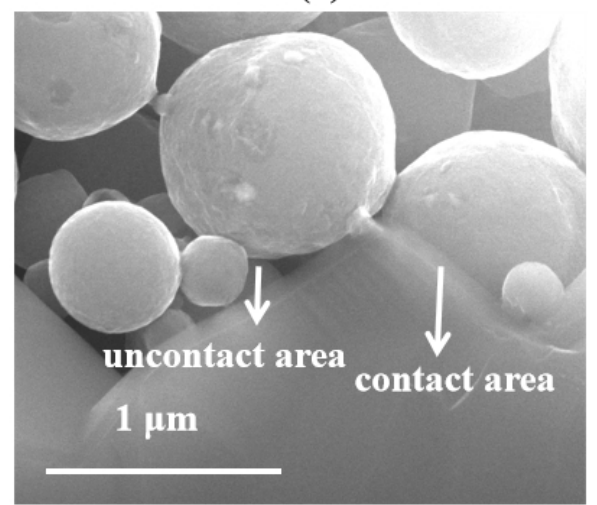

Figure 9. Cross-section SEM images obtained at the metallization/Si contact area of Cell 2: (a) low-magnification images; (b) high-magnification images. The SEM images show a discontinuous contact between the firing-through $\mathrm{Al}$ paste and Si substrate of Cell 2.

According to the above analyses, the high $\mathrm{J}_{0 \text {, metal }}$ of the cell using Ag-Al paste could be attributed to the continuous Ag nano colloids on the Si substrate. For the cell using firing-through Al paste, some of the Si substrates touched by the Al particle reacted with Al violently, forming an inverted pyramid-shaped etched area on the passivation layer, generating a high surface recombination during the current transmission process. The other region without etching maintains good passivation characteristics but cannot collect current from the Si substrate at the same time. Such inhomogeneous contact does not benefit the obtaining of a high efficiency cell. On the other hand, a shallow and homogeneous etching area is necessary for the cell to get a low $\mathrm{J}_{0 \text {, metal }}$ and $\rho_{\mathrm{c}}$.

\subsection{The Effect of Silicon Particle in Aluminum Paste on Ohmic Contact}

N-PERT solar cells using firing-through $\mathrm{Al}$ paste with and without adding Si powder for boron-doped emitter metallization are executed, denoted as Cell 2 and 3, respectively. As reported, the $\mathrm{Si}$ in the $\mathrm{Al}$ paste suppressed the driving force for the strong lateral silicon diffusion towards the Al layer [39-41], initiating low and weak reactivity of the paste. The distribution of measured $\rho_{\mathrm{C}}$ and $\mathrm{V}_{\mathrm{OC}}$ of the investigated solar cells with different $\mathrm{Al}$ paste are shown in Figure 10, and the average value is displayed above each box plot. The $\mathrm{V}_{\mathrm{OC}}$ of Cell 3 was $8 \mathrm{mV}$ higher than Cell 2', but cells' $\rho_{\mathrm{c}}$ were roughly the same, which proves that adding silicon particles to the $\mathrm{Al}$ paste can effectively reduce the solar cell defects. 


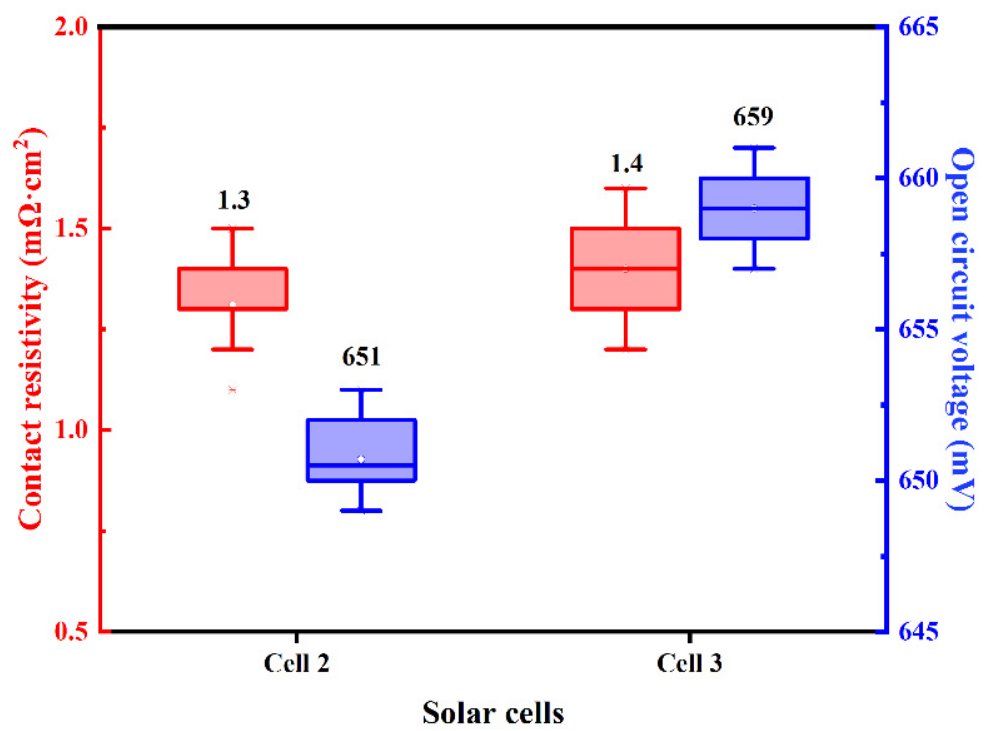

Figure 10. The distribution of the $\rho_{\mathrm{C}}$ and $\mathrm{V}_{\mathrm{OC}}$ of the solar cells using the firing-through $\mathrm{Al}$ paste without and with Si particles.

The two cells' dark J-V curves are shown in Figure 11 to confirm if adding silicon particles can reduce the defects of the cell or not. The leakage current density at the voltage of $-1 \mathrm{~V}$ of Cell 3 is about one order of magnitude smaller than Cell 2, indicating fewer defects in the cell using the Al paste adding Si particles. Cell 3 exhibits better diode properties. In conclusion, we can speculate that the reason for the low reverse leakage of cell 3 is the addition of silicon particles, which reduces the defects caused by the paste on the cell.

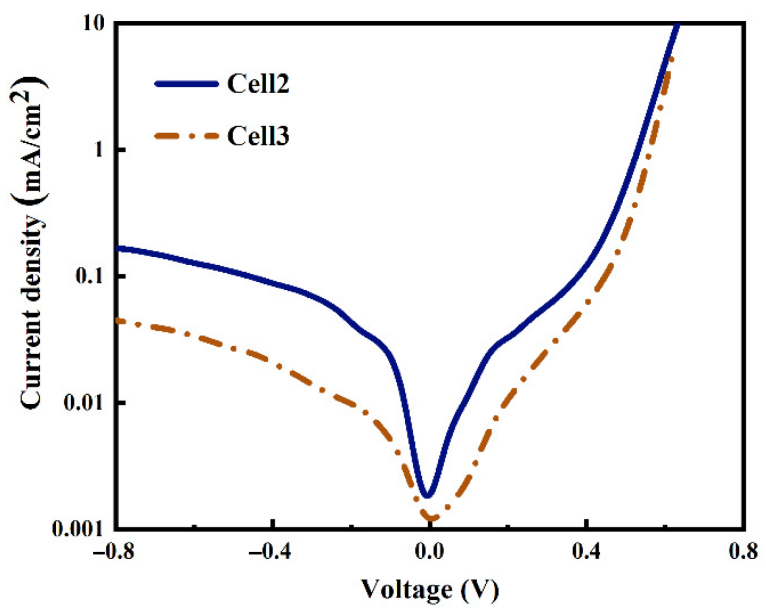

Figure 11. Dark J-V curves of the two cells using firing-through Al paste with and without adding silicon particles.

The micro-contact morphology of the $\mathrm{Si}$ substrate at the $\mathrm{Si} /$ metallization interface has been studied by SEM. Figure 12 shows that the etching areas are smaller and shallower when adding Si particles into the Al paste, which reveals that adding Si particles into the Al paste can prevent the violent reaction between the paste and $\mathrm{SiN}_{\mathrm{x}}$ layer. We can conclude that the Si particle additives can reduce the etching area significantly since the addition of Si particles can reduce the diffusion of silicon from the substrate into the paste. 
(a)

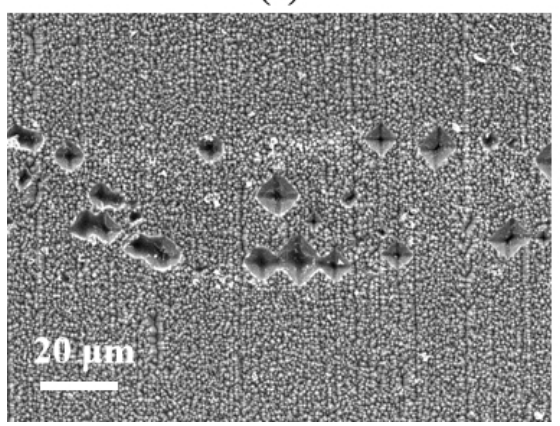

(b)

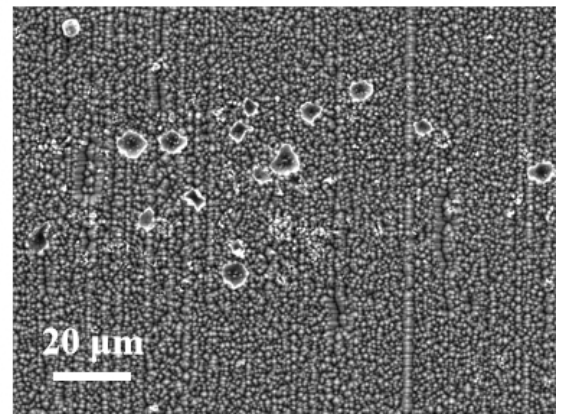

Figure 12. Si substrate surface etched area scanning electron microscope (SEM) images of the cells with (a) and without (b) adding Si particles.

\subsection{The Effect of Aluminum Particle Size on the Cell Electrical Properties}

Since the contact pattern of $\mathrm{Al}$ paste and the boron-doped emitter derived from joints between $\mathrm{Al}$ particles and the pyramid surface texture of the $\mathrm{Si}$ substrate, the contact and etching area depends on the size of $\mathrm{Al}$ particles, which play an important part in contact resistivity. In addition, the different interspaces among Al particles would be involved in the electrical properties of the silicon cell. Silicon solar cells named Cell 2, Cell 4 and Cell 5 were metalized by Al paste with different Al particle size: 1-3 $\mu \mathrm{m}, 5-6 \mu \mathrm{m}, 9-11 \mu \mathrm{m}$, respectively. The distribution of measured $\rho_{\mathrm{C}}$ and $\mathrm{V}_{\mathrm{OC}}$ of the investigated solar cells with different Al paste were shown in Figure 13, the average value displayed above each box plot. It is obvious that the Voc of Cell 5 using an Al particle with 9-11 $\mu \mathrm{m}$ particle size was $30 \mathrm{mV}$ lower than that of Cell 2 using 1-3 $\mu \mathrm{m}$ particle size Al powder. When different particle sizes react with the $\mathrm{Si}$ substrate, the larger particle size $\mathrm{Al}$ powder will damage the substrate more seriously, which will cause the Cell's $V_{O C}$ to decrease.

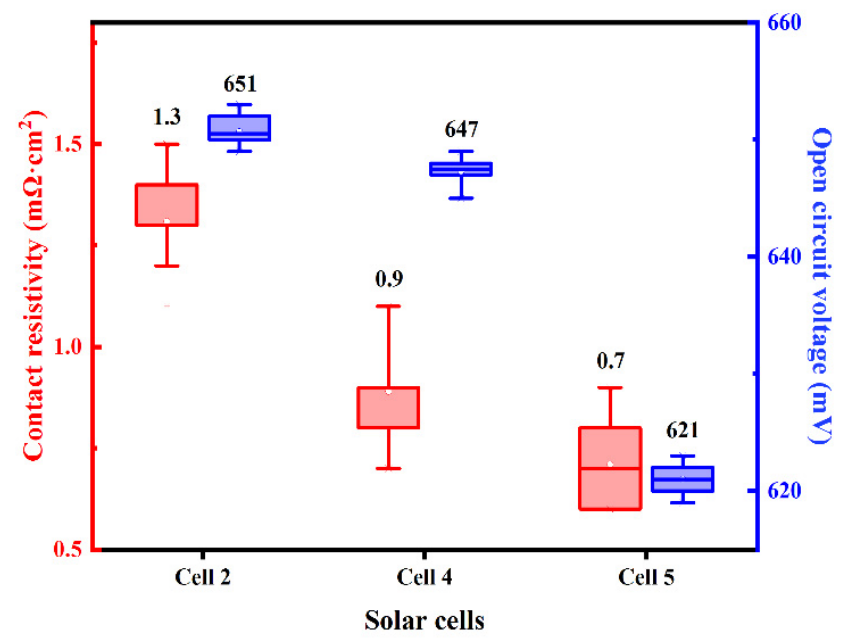

Figure 13. The distribution of the $\rho_{\mathrm{c}}$ and $\mathrm{V}_{\mathrm{OC}}$ of the solar cells using the firing-through $\mathrm{Al}$ paste within different particle size $\mathrm{Al}$ powders.

The cells' dark J-V curves are also plotted in Figure 14. It shows a larger reverse leakage current and lower rectification ratio of the cell when using larger particle size $\mathrm{Al}$ powders, indicating an increment of interfacial recombination and a reduction in the shunt resistance in the cell after the metallization process, consistent with the Voc parameters shown in Figure 13. 


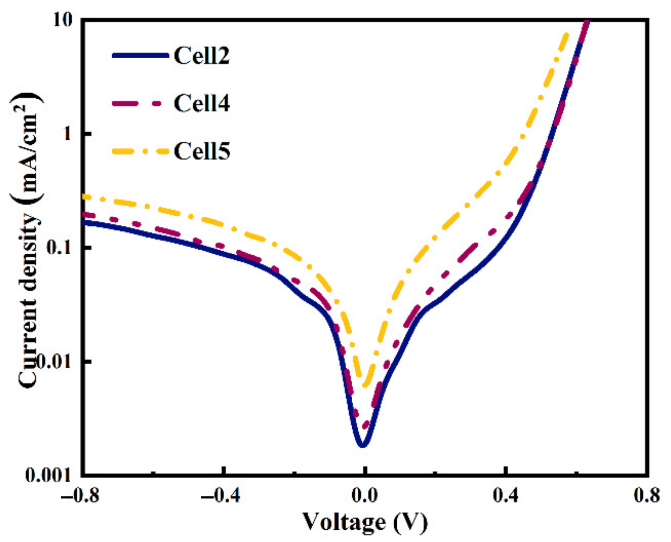

Figure 14. Dark J-V cures of the cells using different particle size Al powders.

The Si / metallization interface and the etched region of Si substrate surface after the paste removal was measured by SEM. As shown in Figure 15, the etched area of the Si substrate is obviously enhanced, with Al powder particle size increasing. Figure $15 \mathrm{c}, \mathrm{f}$ show the $\mathrm{Si}$ /metallization contact area SEM images of Cell 5. As we can see, the etched area of the Si substrate looks like a deep pit, which was caused by the reaction between the large-size Al particles and the Si substrate. Even the p-n junction of the Cell 5 may be destroyed which is only $0.5 \mu \mathrm{m}$ away from the front surface, as the $\mathrm{V}_{\mathrm{OC}}$ of Cell 5 was so low. On the other hand, the Si substrate of Cell 2 in direct contact with the Al particles is more homogeneous in Figure 15a. These direct contact areas allow current to be transmitted, so the contact resistivity of Cell 2 is not particularly high, at $1.3 \mathrm{~m} \Omega \cdot \mathrm{cm}^{2}$. The etching area caused by $\mathrm{Al}$ particles on the Si substrate is so shallow that a high Voc of Cell 2. We can conclude that a more homogeneous etched area of $\mathrm{Si}$ substrate at the $\mathrm{Si} /$ metallization contact interface could be achieved by using smaller particle size Al powder, as this homogeneous etched Si substrate is more conducive to balancing the Cell current transmission and recombination.

(a)

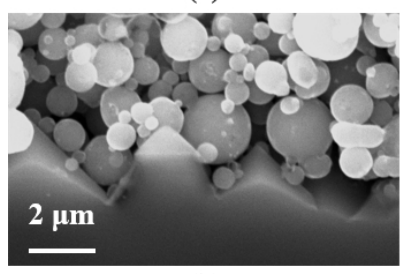

(b)

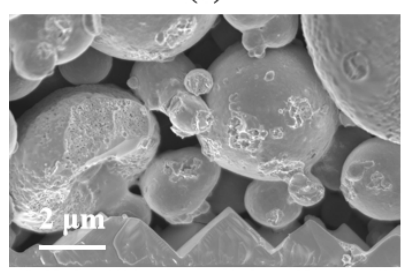

(c)

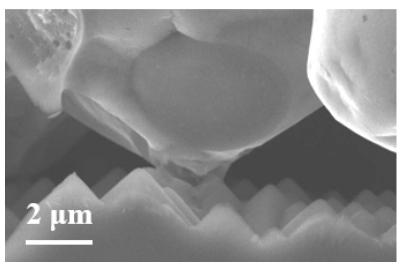

(d)

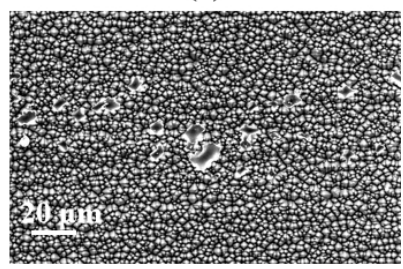

(e)

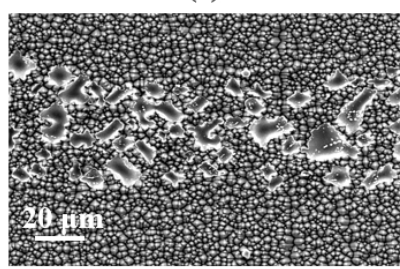

(f)

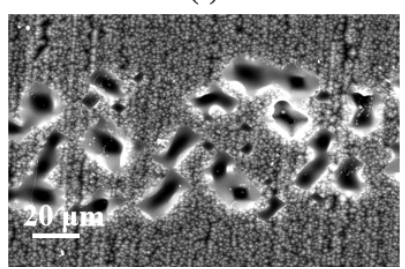

Figure 15. (a-c) Cross section SEM images; (d-f) Si substrate surface etched area after the paste's removal. 
Based on the above, it is considered that the semiconductor-metal contact takes place through the glass frit attached to the $\mathrm{Al}$ particle reacting with the passivation layer $\left(\mathrm{SiN}_{\mathrm{x}}\right)$, associated with the size of the etched area. It is suggested that using smaller particle size powder is the better choice to reduce the deep etch area and obtain uniform contact to balance the contact resistivity and surface recombination.

3.4. The Electrical Characteristics and Micro-Contact of Solar Cells with Silver Aluminum Paste and Improved Firing-Through Aluminum Paste on the N-Pert Solar Cell

$\mathrm{N}$-PERT solar cells using improved firing-through $\mathrm{Al}$ paste on the front boron emitter were carried out, named Cell 6 . The improved $\mathrm{Al}$ paste was mainly prepared by adding appropriate content of Si powder and using Al powder with a particle size of 1-2 $\mu \mathrm{m}$. The electrical characterization of the cells under 1 sun light illumination is listed in Table 1. The Jsc and FF are the abbreviations of saturation recobination current densities and fill factor. Cell 6 using improved firing-through Al paste shows a higher open circuit voltage $\left(\mathrm{V}_{\mathrm{OC}}\right)$, but a higher series resistance $\left(\mathrm{R}_{\mathrm{S}}\right)$ leading to a loss of actual efficiency (Eff). The $R_{S}$ difference of the two cells is mainly related to the front paste fingers' resistance and the contact resistance between the paste and the Si substrate as the two cells have used the same Si wafer and rear paste. The higher series resistance of Cell 6 than Cell 1 was mainly due to the line resistivity of Al finger $\left(4 \times 10^{-5} \Omega \cdot \mathrm{cm}\right)$, higher than the Ag-Al finger $\left(4 \times 10^{-6} \Omega \cdot \mathrm{cm}\right)$.

Table 1. The electrical characteristics of the solar cells under 1 sun light illumination.

\begin{tabular}{cccccc}
\hline Solar Cells & $\mathbf{V}_{\text {OC }}(\mathbf{m V})$ & JSC $_{\left(\mathbf{m A} / \mathbf{c m}^{\mathbf{2}}\right)}$ & FF (\%) & Eff (\%) & $\mathbf{R}_{\mathbf{S}}(\mathbf{\Omega})$ \\
\hline Cell 1 & 648 & 40.15 & 79.76 & 20.88 & 0.0017 \\
Cell 6 & 655 & 39.59 & 76.06 & 19.71 & 0.0034 \\
\hline
\end{tabular}

The implied electrical characteristics of Cell 1 and Cell 6 measured by Suns- $V_{O C}$ are shown in Table 2. The implied $\mathrm{V}_{\mathrm{OC}}$ (i-Voc), pseudo fill factor (pFF), pseudo efficiency (pEff) and the first diode saturation recobination current densities $\left(\mathrm{J}_{01}\right)$ was $655 \mathrm{mV}, 83.48 \%$, $21.34 \%, 347 \mathrm{fA} / \mathrm{cm}^{2}$, respectively. It demonstrates that a great improvement in cell implied electrical performance is achieved using low recombination $\mathrm{Al}$ paste comparing with Ag-Al paste.

Table 2. The metal recombination, contact resistivity and implied electrical characteristics of the solar cells when use $\mathrm{Ag}$-Al paste and improved firing-through $\mathrm{Al}$ paste.

\begin{tabular}{ccccc}
\hline Solar Cells & i-V $\mathbf{\text { OC }}(\mathbf{m V})$ & pFF (\%) & pEff (\%) & $\mathbf{J}_{\mathbf{0 1}}\left(\mathbf{f A} / \mathbf{c m}^{\mathbf{2}}\right)$ \\
\hline Cell 1 & 648 & 82.73 & 21.00 & 382 \\
Cell 6 & 655 & 83.48 & 21.34 & 347 \\
\hline
\end{tabular}

The distribution of measured $\rho_{\mathrm{c}}$ and $\mathrm{V}_{\mathrm{OC}}$ of Cell 1 and Cell 6 with Ag-Al paste and improved firing-through Al paste are shown in Figure 16, and the average value is displayed above each box plot. Low $\rho_{\mathrm{C}}$ and high $\mathrm{V}_{\mathrm{OC}}$ were obtained using the improved firing-through $\mathrm{Al}$ paste.

Figure 17 shows the $\mathrm{J}_{01}$ of the small solar cells metallized with improved firingthrough $\mathrm{Al}$ paste using the printed pattern as in Figure 3. Low metal recombination $\mathrm{J}_{0 \text {, metal }}$ of $348 \mathrm{fA} / \mathrm{cm}^{2}$ was obtained as shown in Figure 17. 


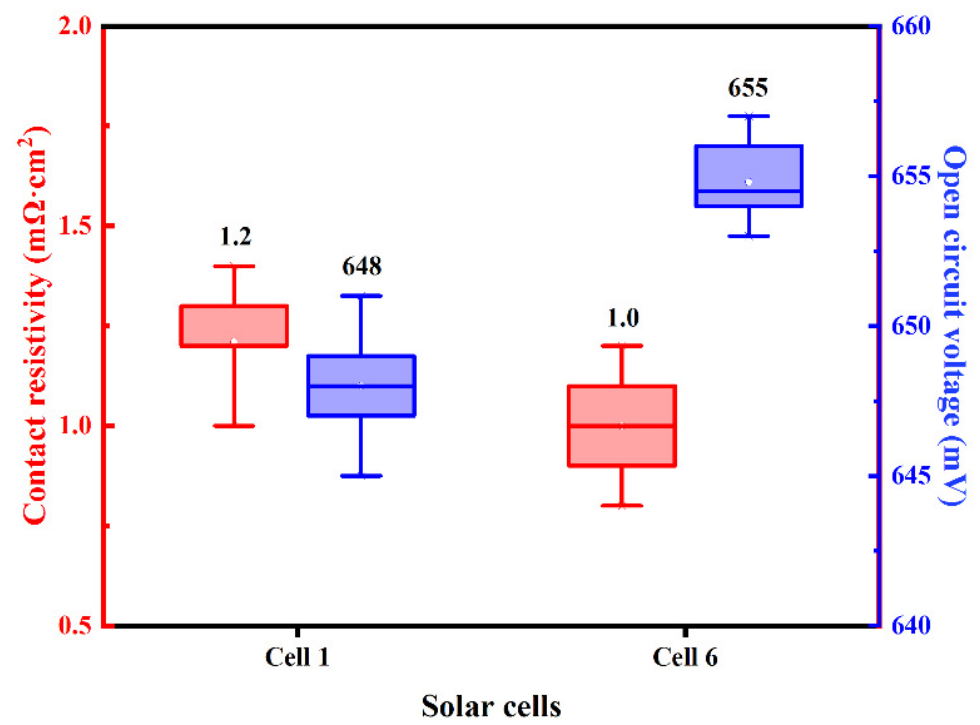

Figure 16. The experimental electrical data distribution of the cells fabricated with Ag-Al paste and improved firing-through $\mathrm{Al}$ paste.

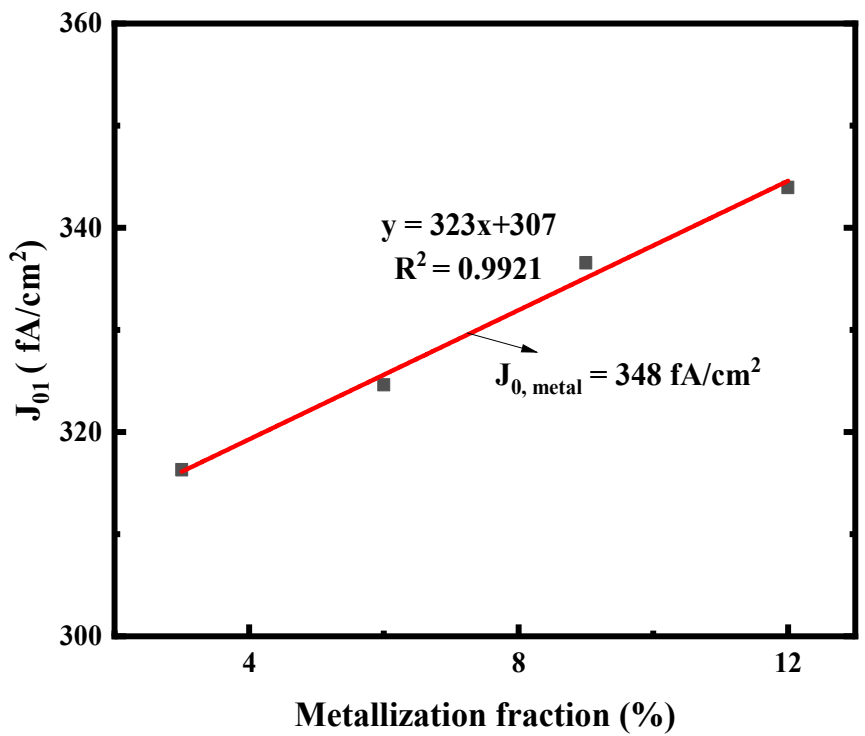

Figure 17. $\mathrm{J}_{01}$ extracted from Suns- $\mathrm{V}_{\mathrm{OC}}$ as a function of metal fraction variation on the cell boron emitter. The $\mathrm{J}_{0}$, metal is then extracted from the linear fit (solid lines).

Figure 18 shows the SEM images of Cell 6 obtained at the Si/metallization interface after the paste removal. This reveals that the homogeneous and shallow etching area on the Si substrate induces a low metal recombination and low contact resistivity. We are trying to reduce the series resistance of the cell using this firing-through Al paste, which can be achieved by designing dense grid lines and printing silver paste on the firing-through Al paste. 


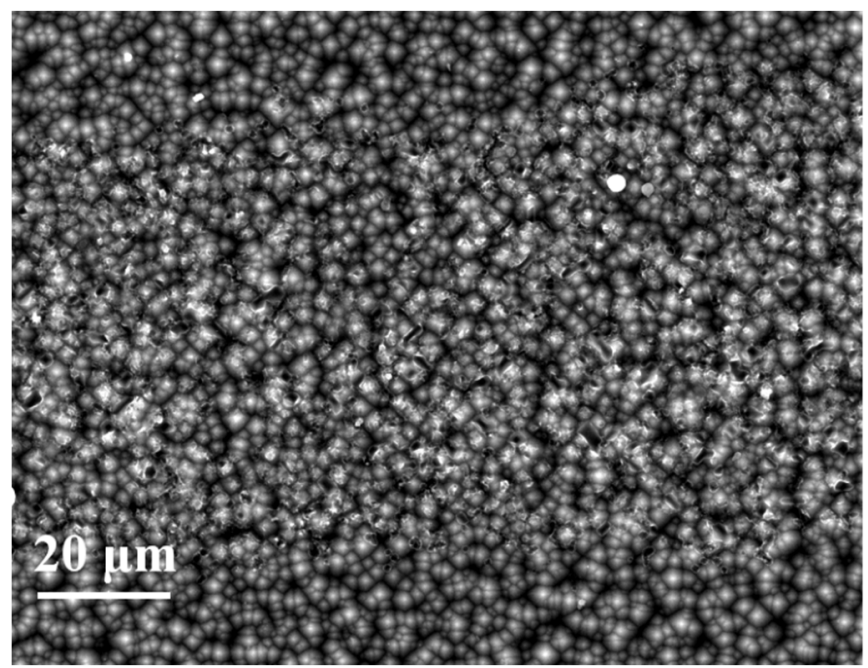

Figure 18. Si substrate surface etched area SEM images obtained at the Si/metallization interface of Cell 6 after the paste removal.

\section{Conclusions}

In this work, a kind of low recombination firing-through aluminum screen-printing paste on the front side for the metallization of silicon solar cell was presented. The firethrough contact approach for the N-PERT with screen printed contacts was evaluated. The electrical properties and the analysis of $\mathrm{Si} /$ metallization micro-structure were investigated in detail.

Microstructure analysis indicated that a shallow and homogeneous etching area of $\mathrm{Si}$ substrate was necessary for balancing the $\mathrm{Si}$ /metallization interface recombination and contact resistivity. Adding Si particles to the paste can conspicuously attenuate the reaction between the paste and the Si substrate, in order to achieve low recombination of the reduced cell and corresponding low contact resistivity. In addition, the utility of small particle size $\mathrm{Al}$ powders can make the paste and the silicon substrate contact more homogeneous. The test results evince that small $\mathrm{Al}$ particles cause no extra deep etching area to Si substrate, which accounts for the lower recombination and suitable contact resistivity of cells.

The results of this work make it clear that high open circuit voltage and low contact resistivity could be realized by using our $\mathrm{Al}$ paste. Outstanding electrical properties could be obtained. The lower $\mathrm{J}_{0 \text {, metal }}$ of $348 \mathrm{fA} / \mathrm{cm}^{2}\left(890 \mathrm{fA} / \mathrm{cm}^{2}\right.$ for Ag-Al paste) and higher pseudo-efficiency of $21.34 \%$ when using the $\mathrm{Al}$ paste for front side metallization were obtained compared with that of cells using Ag-Al paste. Although the non-optimal $\rho_{\mathrm{c}}$ of the fire-through contacts has been reported earlier, a low $\rho_{\mathrm{c}}$ value for the $\mathrm{N}$-type silicon cell could be realized via our work.

Author Contributions: Conceptualization, P.Z. and Y.L.; Data curation, P.Z. and J.T.; Formal analysis, C.C., and J.T.; Funding acquisition, Y.L., P.Z. and D.W.; Investigation, C.C., A.Z. and J.T.; Methodology, Y.L. and C.C.; Project administration, P.Z., Y.L. and C.C.; Resources, A.Z.; Software, A.Z.; Supervision, Y.L., P.Z. and D.W.; Validation, A.Z.; Writing—original draft, P.Z.; Writing—review \& editing, Y.L., P.Z. and D.W. All authors have read and agreed to the published version of the manuscript.

Funding: This research was funded by Special Fund for S\&T achievements transformation of Jiangsu province, grant number BA2017117, Science and Technology Program of Nantong (No. JC2018023), Science and Technology program of Jiangsu province, grant number: BY2016053-09, and the National Natural Science Foundation of China (No. 61774140), Jiangsu Province Cultivation base for State Key Laboratory of Photovoltaic Science and Technology.

Institutional Review Board Statement: Not applicable.

Informed Consent Statement: Not applicable. 
Data Availability Statement: Data is contained within the article.

Conflicts of Interest: The authors declare no conflict of interest.

\section{References}

1. Blakers, A.W.; Wang, A.; Milne, A.M.; Zhao, J.; Green, M.A. 22.8\% efficient silicon solar cell. Appl. Phys. Lett. 1989, 55, 1363-1365. [CrossRef]

2. Rehman, A.U.; Lee, S.H. Advancements in n-Type Base Crystalline Silicon Solar Cells and Their Emergence in the Photovoltaic Industry. Sci. World J. 2013, 2013, 1-13. [CrossRef]

3. Cuevas, A.; Kerr, M.J.; Samundsett, C.; Ferrazza, F.; Coletti, G. Millisecond minority carrier lifetimes in n-type multicrystalline silicon. Appl. Phys. Lett. 2002, 81, 4952-4954. [CrossRef]

4. Glunz, S.W.; Rein, S.; Lee, J.Y.; Warta, W. Minority carrier lifetime degradation in boron-doped Czochralski silicon. J. Appl. Phys. 2001, 90, 2397-2404. [CrossRef]

5. Bock, R.; Schmidt, J.; Mau, S.; Hoex, B. The ALU+ concept: N-type silicon solar cells with surface-passivated screen-printed aluminum-alloyed rear emitter. In Proceedings of the 34th IEEE Photovoltaic Specialists Conference (PVSC), Philadelphia, PA, USA, 7-12 June 2009.

6. Cotter, J.; Guo, J.; Cousins, P.; Abbott, M.; Chen, F.; Fisher, K. P-Type Versus n-Type Silicon Wafers: Prospects for High-Efficiency Commercial Silicon Solar Cells. IEEE Trans. Electron Devices 2006, 53, 1893-1901. [CrossRef]

7. Macdonald, D.; Geerligs, L.J. Recombination activity of interstitial iron and other transition metal point defects in p-and n-type crystalline silicon. Appl. Phys. Lett. 2004, 85, 4061-4063. [CrossRef]

8. Pysch, D.; Mette, A.; Filipovic, A.; Glunz, S.W. Comprehensive analysis of advanced solar cell contacts consisting of printed fine-line seed layers thickened by silver plating. Prog. Photovolt. Res. Appl. 2009, 17, 101-114. [CrossRef]

9. Kumar, P.; Pfeffer, M.; Willsch, B.; Eibl, O. Contact formation of front side metallization in p-type, single crystalline Si solar cells: Microstructure, temperature dependent series resistance and percolation model. Sol. Energy Mater. Sol. Cells 2016, 145, 358-367. [CrossRef]

10. Hilali, M.M.; Sridharan, S.; Khadilkar, C.; Shaikh, A.; Rohatgi, A.; Kim, S. Effect of glass frit chemistry on the physical and electrical properties of thick-film Ag contacts for silicon solar cells. J. Electron. Mater. 2006, 35, 2041-2047. [CrossRef]

11. Li, Z.G.; Liang, L.; Cheng, L.K. Electron microscopy study of front-side Ag contact in crystalline Si solar cells. J. Appl. Phys. 2009, 105, 66102. [CrossRef]

12. Kumar, P.; Aabdin, Z.; Pfeffer, M.; Eibl, O. High-efficiency, single-crystalline, p- and n-type Si solar cells: Microstructure and chemical analysis of the glass layer. Sol. Energy Mater. Sol. Cells 2018, 178, 52-64. [CrossRef]

13. Lin, C.-H.; Tsai, S.-Y.; Hsu, S.-P.; Hsieh, M.-H. Investigation of Ag-bulk/glassy-phase/Si heterostructures of printed Ag contacts on crystalline Si solar cells. Sol. Energy Mater. Sol. Cells 2008, 92, 1011-1015. [CrossRef]

14. Hong, K.-K.; Cho, S.-B.; You, J.S.; Jeong, J.-W.; Bea, S.-M.; Huh, J.-Y. Mechanism for the formation of Ag crystallites in the Ag thick-film contacts of crystalline Si solar cells. Sol. Energy Mater. Sol. Cells 2009, 93, 898-904. [CrossRef]

15. Li, Z.G.; Liang, L.; Ionkin, A.S.; Fish, B.M.; Lewittes, M.E.; Cheng, L.K.; Mikeska, K.R. Microstructural comparison of silicon solar cells' front-side Ag contact and the evolution of current conduction mechanisms. J. Appl. Phys. 2011, 110, 074304. [CrossRef]

16. Ballif, C.; Huljić, D.M.; Willeke, G.; Hessler-Wyser, A. Silver thick-film contacts on highly doped n-type silicon emitters: Structural and electronic properties of the interface. Appl. Phys. Lett. 2003, 82, 1878-1880. [CrossRef]

17. Butler, K.T.; Vullum, P.E.; Muggerud, A.M.; Cabrera, E.; Harding, J. Structural and electronic properties of silver/silicon interfaces and implications for solar cell performance. Phys. Rev. B 2011, 83. [CrossRef]

18. Fritz, S.; Riegel, S.; Hammud, A.; Deniz, H.; Hahn, G. Crystalline Nature of Metal Spikes and Silicon Inclusions in Ag/Al Screen-Printing Metallization. IEEE J. Photovolt. 2016, 6, 79-85. [CrossRef]

19. Fritz, S.; Konig, M.; Riegel, S.; Herguth, A.; Horteis, M.; Hahn, G. Formation of Ag/Al Screen-Printing Contacts on B Emitters. IEEE J. Photovolt. 2015, 5, 145-151. [CrossRef]

20. Heinz, F.D.; Breitwieser, M.; Gundel, P.; König, M.; Hörteis, M.; Warta, W.; Schubert, M.C. Microscopic origin of the aluminum assisted spiking effects in n-type silicon solar cells. Sol. Energy Mater. Sol. C 2015, 131, 105-109. [CrossRef]

21. Kumar, P.; Pfeffer, M.; Willsch, B.; Eibl, O.; Koduvelikulathu, L.J.; Mihailetchi, V.D.; Kopecek, R. N-type single-crystalline Si solar cells: Front side metallization for solar cells reaching 20\% efficiency. Sol. Energy Mater. Sol. Cells 2016, 157, 200-208. [CrossRef]

22. Wu, W.; Roelofs, K.E.; Subramoney, S.; Lloyd, K.; Zhang, L. Role of aluminum in silver paste contact to boron-doped silicon emitters. AIP Adv. 2017, 7, 15306. [CrossRef]

23. Lago, R.; Perez, L.; Kerp, H.; Freire, I.; Hoces, I.; Azkona, N.; Recart, F.; Jimeno, J.C. Screen printing metallization of boron emitters. Prog. Photovolt. Res. Appl. 2010, 18, 20-27. [CrossRef]

24. Kiefer, F.; Krugener, J.; Heinemeyer, F.; Osten, H.J.; Brendel, R.; Peibst, R. Structural Investigation of Printed Ag/Al Contacts on Silicon and Numerical Modeling of Their Contact Recombination. IEEE J. Photovolt. 2016, 6, 1175-1182. [CrossRef]

25. Körner, S.; Kiefer, F.; Peibst, R.; Heinemeyer, F.; Krügener, J.; Eberstein, M. Basic Study on the Influence of Glass Composition and Aluminum Content on the Ag/Al Paste Contact Formation to Boron Emitters. Energy Procedia 2015, 67, 20-30. [CrossRef]

26. Fritz, S.; Engelhardt, J.; Ebert, S.; Hahn, S. Contacting boron emitters on n-type silicon solar cells with aluminum-free silver screen-printing pastes. Phys. Status Solidi 2016, 10, 305-309. 
27. Kiefer, F.; Peibst, R.; Ohrdes, T.; Dullweber, T.; Krügener, J.; Osten, H.J.; Schöllhorn, C.; Grohe, A.; Brendel, A. Influence of the boron emitter profile on Voc and Jsc losses in fully ion implanted n-type PERT solar cells. Phys. Status Solidi 2015, 212, $291-297$.

28. Lohmüller, E.; Werner, S.; Hoenig, R.; Greulich, J.; Clement, F. Impact of boron doping profiles on the specific contact resistance of screen printed Ag-Al contacts on silicon. Sol. Energy Mater. Sol. C 2015, 142, 2-11. [CrossRef]

29. Narasimha, S.; Rohatgi, A.; Weeber, A.W. An optimized rapid aluminum back surface field technique for silicon solar cells. IEEE Trans. Electron Dev. 1999, 46, 1363-1370. [CrossRef]

30. Lauermann, T.; Fröhlich, B.; Hahn, G.; Terheiden, B. Diffusion-based model of local Al back surface field formation for industrial passivated emitter and rear cell solar cells. Prog. Photovolt. Res. Appl. 2015, 23, 10-18. [CrossRef]

31. Krause, J.; Woehl, R.; Rauer, M.; Schmiga, C.; Wilde, J.; Biro, D. Microstructural and electrical properties of different-sized aluminum-alloyed contacts and their layer system on silicon surfaces. Sol. Energy Mater. Sol. Cells 2011, 95, 2151-2160. [CrossRef]

32. Muller, J.; Bothe, K.; Gatz, S.; Plagwitz, H.; Schubert, G.; Brendel, R. Contact Formation and Recombination at Screen-Printed Local Aluminum-Alloyed Silicon Solar Cell Base Contacts. IEEE Trans. Electron Devices 2011, 58, 3239-3245. [CrossRef]

33. Thaidigsmann, B.; Kick, C.; Drews, A.; Clement, F.; Wolf, A.; Biro, D. Fire-through contacts-A new approach to contact the rear side of passivated silicon solar cells. Sol. Energy Mater. Sol. Cells 2013, 108, 164-169. [CrossRef]

34. Gullu, H.H.; Yildiz, D.E.; Kocyigit, A.; Yıldırım, M. Electrical properties of Al/PCBM:ZnO/p-Si heterojunction for photodiode application. J. Alloys Compd. 2020, 827, 154279. [CrossRef]

35. Vinod, P.N. Specific contact resistance measurements of the screen-printed Ag thick film contacts in the silicon solar cells by three-point probe methodology and TLM method. J. Mater. Sci. Mater. Electron. 2011, 22, 1248-1257. [CrossRef]

36. Fellmeth, T.; Born, A.; Kimmerle, A.; Clement, F.; Biro, D.; Preu, R. Recombination at Metal-Emitter Interfaces of Front Contact Technologies for Highly Efficient Silicon Solar Cells. Energy Procedia 2011, 8, 115-121. [CrossRef]

37. Edler, A.; Mihailetchi, V.D.; Koduvelikulathu, L.J.; Comparotto, C.; Kopecek, R.; Harney, R. Metallization-induced recombination losses of bifacial silicon solar cells. Prog. Photovolt. 2015, 23, 620-627. [CrossRef]

38. Kiefer, F.; Peibst, R.; Ohrdes, T.; Krügener, J.; Osten, H.J.; Brendel, R. Emitter Recombination Current Densities of Boron Emitters with Silver/Aluminum Pastes. In Proceedings of the 40th IEEE Photovoltaic Specialists Conference (PVSC), Denver, CO, USA, 8-13 June 2014; pp. 2808-2812.

39. Rauer, M.; Woehl, R.; Ruhle, K.; Schmiga, C.; Hermle, M.; Horteis, M.; Biro, D. Aluminum Alloying in Local Contact Areas on Dielectrically Passivated Rear Surfaces of Silicon Solar Cells. IEEE Electron Device Lett. 2011, 32, 916-918. [CrossRef]

40. Joonwichien, S.; Utsunomiya, S.; Kida, Y.; Moriya, M.; Shirasawa, K.; Takato, H. Improved Rear Local Contact Formation Using Al Paste Containing Si for Industrial PERC Solar Cell. IEEE J. Photovolt. 2018, 8, 54-58. [CrossRef]

41. Dullweber, T.; Kranz, C.; Peibst, R.; Baumann, U.; Hannebauer, H.; Fülle, A.; Steckemetz, S.; Weber, T.; Kutzer, M.; Müller, M.; et al. PERC+: Industrial PERC solar cells with rear Al grid enabling bifaciality and reduced Al paste consumption. Prog. Photovolt. Res. Appl. 2016, 24, 1487-1498. [CrossRef] 